\title{
THE BANKRUPTCY PREFERENCE CHALLENGE TO AFTER-ACQUIRED PROPERTY CLAUSES UNDER THE CODE *
}

\author{
HAROLD FrIEDMAN $\dagger$
}

\section{INTRODUCTION}

Financing against the security of after-acquired personal property has traditionally been a risky endeavor for the secured creditor. Purchasers of the after-acquired property and creditors with liens upon it have often been held to have interests superior to the secured creditor's; his financing arrangement has frequently become a partly or wholly unsecured transaction. When an after-acquired property clause was applied to inventory, accounts receivable, or both, the risks to the financer multiplied. Many courts were quick to find fraud-in-law in a scheme that permitted continuing shift in the debtor's stock and accounts as goods were sold and receivables collected-especially when the debtor was given complete freedom to dispose of the chattels and proceeds. ${ }^{1}$ Characterized by narrow legal distinctions and stringent requirements, the body of law surrounding secured transactions has been and remains highly complex and confusing for even the most skilled. $^{2}$

Article 9 of the Uniform Commercial Code was drafted to reduce the complexity of financing against personalty in secured commercial transactions. $^{3}$ Its success cannot be definitively determined at present since its provisions have barely been subject to the tests of litigation in the five states which have adopted the Code. ${ }^{4}$ It is fair to predict,

* The author is indebted to Professor Grant Gilmore of the Yale Law School who suggested the topic for this Article and whose comments and criticisms were invaluable.

$\doteqdot$ B.A., 1956, LL.B., 1959, Yale University.

1 For a discussion of the common-law fraud doctrines see Cohen \& Gerber, Mortgages of Merchandise, 39 Colum. L. Rev. 1338 (1939). Benedict v. Ratner, 268 U.S. 353 (1925), is the leading case influencing the fraud-in-law doctrine on assignments of accounts receivable. For the implications and complexities of using accounts receivable as collateral see Comment, 67 Y ALE L.J. 402 (1958). The doctrine of Benedict has also been applied in the field of tangible chattel financing. See Comment, 67 Yale L.J. 1024, 1036 (1958). See also Cohen \& Gerber, Mortgages of Accounts Receivable, 29 Geo. L.J. 555, 559 (1941).

2 For a comprehensive treatment of the problems and difficulties of personal property financing see Gilmore, Chattel Security (pts. 1-2), 57 YALE L.J. 517, 761 (1948).

3 See UnIform Commerctal Code [hereinafter cited as UCC] §9-101, comment.

4 Conn. Acts 1959, Public Act No. 133 (effective Oct. 1, 1961) ; Ky. Acts 1958, ch. 77, at 214 (effective July 1, 1960); Mass. ANN. LAws ch. 106 (1958) ; N.H. Laws 1959, ch. 247, \&1 (effective July 1, 1961) ; PA. Stat. ANN. tit. 12A (1954), as amended, Pa. Laws 1959, No. 426 (effective Jan. 1, 1960). 
however, that it should make for a safer and more flexible system of financing.

The core of article 9 is the "floating lien" whereby a seller or lender may obtain as collateral for credit a security interest in virtually all of his debtor's property, tangible and intangible. ${ }^{5}$ If provided for in the security agreement, the security interest can cover goods held for resale, ${ }^{6}$ shifting masses of property, ${ }^{7}$ proceeds arising from sale of secured property, ${ }^{8}$ and practically all property to be acquired in the future. ${ }^{9}$ A secured creditor can insulate himself from the claims of subsequent purchasers and third party creditors ${ }^{10}$ by compliance with the simple notice filing provisions ${ }^{11}$ which perfect the security interest. ${ }^{12}$ Only holders of prior security interests in the property, ${ }^{13}$ holders of purchase money secured interests prior or subsequent, ${ }^{14}$ and purchasers in the ordinary course of business of property held by the debtor for resale, ${ }^{15}$ can prevail over the holder of the perfected security interest.

But the real threat to article 9 transactions is posed by the trustee in bankruptcy; ${ }^{16}$ and this is so despite an attempt by the drafters to frame the Code provisions in a manner designed to escape the wide avoidance powers of the trustee. ${ }^{17}$ By section 60 of the Bankruptcy Act, ${ }^{18}$ the trustee can void certain transfers (including secured financing agreements) as preferences even though there has been strict compliance with the state law governing security perfection; transfer to a creditor within four months of bankruptcy in full or partial satisfaction

5 See UCC $\$ 9-204$, comment 3.

6 UCC $\$ \S 9-205,-201$.

7 UCC $\$ \S 9-205,-204,-201$.

8 UCC $\$ \$ 9-306,-205$.

จ UCC $\S 9-204,-108$.

10 UCC $\$ \$ 9-201,-301,-303,-204$.

11 UCC $\$ \$ 9-402,-403$.

12 See UCC $\$ 9-312$ on priorities and $\$ \S 9-302,-303,-304,-305,-306,-204$ and cross references for the necessary steps in perfection.

13 UCC $\$ 9-312$.

14 UCC $\$ 312(3)$, (4). See note 107 infra.

15 UCC \& 9-307.

16 Bankruptcy has always been "the crucible in which security is tested." Everett, Securing Security, 16 LAW \& Contemp. Prob. 49 (1951). See Moore \& Tone, Proposed Bankruptcy Amendments: Improvement or Retrogression?, 57 YALE L.J. 683, 691-92 (1948), where it is stated that "Section 60 has always been and is . . . [designed] . . to give the trustee the power to avoid certain transactions denominated as preferential although no creditor could attack them under state law."

17 See UCC §9-108, comment 1. See also text following note 97 infra. For articles dealing with the impact of bankruptcy on article 9 see Countryman, The Secured Transactions Article of the Commercial Code and Section 60 of the Bankruptcy Act, 16 LAW \& Contenrp. Prob. 76 (1951). See also Comment, 2 VirL. L. REv. 395 (1957). Two excellent symposia on secured commercial transactions and the UCC appear in volumes 13 and 16 of Law and Contemporary Problems.

1830 Stat. 562 (1898), as amended, 11 U.S.C. $\$ 96$ (1958) [hereinafter cited by act section number]. 
of an antecedent debt is voidable if all the other elements of a preference exist. ${ }^{19}$ Such property may be reached by the trustee for the benefit of all the general creditors.

Under section 60 it becomes essential to the financer to determine if and when the acquisition of a secured interest in after-acquired property under a security agreement becomes a transfer for an antecedent debt. On the assumption that an after-acquired property transaction could be so held preferential under the other provisions of the Code, the Code's draftsmen inserted what is now section 9-108, which provides that as to future property acquired by the debtor in the ordinary course of business or pursuant to a contract of purchase contemplated by the security agreement, the property will be deemed to be taken for new value and not transferred for an antecedent debt. This is so whether or not new value was in fact given at the time the future property was acquired:

"Where a secured party makes an advance, incurs an obligation, releases a perfected security interest, or otherwise gives new value which is to be secured in whole or in part by after-acquired property his security interest in the after-acquired property shall be deemed to be taken for new value and not as security for an antecedent debt if the debtor acquires his rights in such collateral either in the ordinary course of business or under a contract of purchase made pursuant to the security agreement within a reasonable time after new value is given."

The purpose of this Article is to analyze the problems raised by section 9-108. One cannot predict with assurance whether this section, as it now exists, will prevent the trustee from utilizing section 60 to overturn security interests claimed under after-acquired property clauses, but it is submitted that it is questionable whether a Codesanctioned after-acquired property interest, even in the absence of section $9-108$, is subject to challenge as a preference. In exploring these problems it will be necessary to trace the origin of after-acquired property concepts and the history of their treatment in bankruptcy under preference attack. It will also be necessary to examine the development of section 60 of the Bankruptcy Act. It is hoped that such a study

19 There are essentially six elements of a preference. Under present bankruptcy law, if the debtor (1) makes or suffers to be made a transfer of his property (2) to or for the benefit of a creditor (3) for or on account of an antecedent debt (4) while insolvent and (5) within four months of filing the bankruptcy petition (6) the effect of which will be to enable the creditor to obtain a greater percentage of his debt than some other creditor of the same class, then the debtor has effected a preference. Section $60 \mathrm{a}(1)$. But in order to avoid a transfer and to recover its value from the creditor the trustee must prove that the creditor had actual knowledge or reasonable cause to believe that the debtor was insolvent. Section $60 \mathrm{~b}$. 
will support the author's contentions that section 9-108: (1) is probably unnecessary; (2) is quite likely self-defeating; (3) attempts, however, to bring about a commercially desirable result; and (4) should be rewritten or amended to effectuate this result.

\section{Origin of the After-Acouired Property Clause}

An after-acquired property clause is a provision in a security agreement which gives the secured creditor, as additional collateral, property to be acquired by the debtor subsequent to the execution of the agreement. The property acquired in the future becomes a part of the collateral by virtue of the original instrument, although, as will be indicated below, some further act of transfer may be needed to perfect the secured creditor's interest in this property.

The most common early financing instrument was the chattel mortgage on tangible property. Prior to the 19 th Century a clause in a mortgage attempting to encumber after-acquired personal property gave rise to no specifically enforceable property interest, although an action for damages might lie for breach of the clause. ${ }^{20}$ The reason given by those early courts was simply that " 'a man cannot grant or charge that which he hath not." 21 But the early hostility to such clauses was eventually broken by the persistent efforts of secured creditors. The mortgage on after-acquired property became effective to create a property right (lien) in the future property, and the charge was sufficient to prevail over third party creditors, purchasers and subsequent mortgagees. ${ }^{22}$

At first property already in existence but not yet owned was held transferable in a mortgage; then property with potential existence could be made part of the collateral; and finally property to be created in the future was given this same status. Within this framework states developed their own rules of limitations on the types of future property that could be embraced by an after-acquired property clause. ${ }^{23}$ Thus while one state might have allowed a mortgage upon future property connected with the business of the mortgagor, another might have limited such a mortgage to increases in animal livestock. ${ }^{24}$

20 Williston, Transfers of After-Acquired Personal Property, 19 Harv. L. Rev. 557 (1906). The clause was treated as a contractual obligation but it was not specifically enforceable at the outset. The action for damages, of course, was worthless if the debtor was insolvent.

21 Cohen \& Gerber, The After-Acquired Property Clanse, 87 U. PA. L. REv. 635 (1939) (quoting from Perkins, Profitable Book * 15).

22 Id. at 638.

23 Blair, The Allocation of After-Acquired Mortgaged Property Among Rival Claimants, 40 HARV. L. REv. 222 (1926).

24 See Cohen \& Gerber, supra note 21, at 640, comparing early Michigan and Kentucky security law. 
Mitchell v. Winslow, ${ }^{25}$ decided in 1843, was the first American case clearly establishing the rights of the mortgagee upon bankruptcy of the mortgagor. Here the mortgage, covering machinery, tools, and the mortgagor's stock in trade, contained an after-acquired property clause; it was properly recorded under Maine law at the time the consideration for the mortgage was given. When the mortgagor became a bankrupt under the 1841 Bankruptcy Act, Mr. Justice Story found that the mortgage was perfected as to all creditors at the date of recordation. He held that the mortgage on the after-acquired property was therefore valid and effective as to the general creditors in the proceedings, analogizing from present assignments of future claims and expectancies which equity held superior to the subsequent "legal" claims of other parties. The mortgagee had taken possession of the goods prior to the institution of the proceedings, ${ }^{26}$ but Story ignored that fact in arriving at his decision. He was concerned that a secret transaction might be fraudulent, but given the recordation of the mortgage, this concern was satisfied. He wrote: "[I]t is true, that the assignment [mortgage] can have no positive operation to transfer, in presenti, property in things not in esse; but it operates by way of present contract, to take effect and attach to the things assigned, when and as soon as they come in esse; and it may be enforced as such a contract in rem, in equity." 27

Such a lien on after-acquired property was "equitable" not because it lacked validity against third parties, but merely because of the forum in which it was technically enforceable, the courts of chancery. The recordation provided the requisite notice to perfect the transfer against all third parties except prior lien holders. ${ }^{28}$ So long as there were words of present transfer, as distinguished from a naked promise to give a lien in the future, ${ }^{29}$ the future property became automatically liened when acquired. The perfection of the original agreement was then sufficient in itself to perfect the lien on the after-acquired property. This rule of complete validity by virtue of the automatic attachment of the mortgage

2517 Fed. Cas. 527 (No. 9673) (Story, Circuit Justice, 1843).

$26 I d$. at 529.

$2 \pi I d$. at 531 .

28 Williston, supra note 20 , at 561 , analogizes the transaction to sales law where "any act of appropriation by the seller which has been assented to by the buyer in advance suffices to pass [legal] title," adding that "the recording acts and [certain doctrines] .. may invalidate such a title." But note that in Mitchell $v$. Winsloz, Story has given full effect to the title of the mortgagee, which is not reduced by the recording act but rather protected by it, and that no specific appropriation is required to bind the future goods.

29 Union Trust Co. v. Bulkeley, 150 Fed. 510 (6th Cir. 1907), describes this requirement. See discussion of the case at text accompanying notes 65-67 infra. 
lien to subsequently acquired property will for purposes of this Article be denominated the "automatic perfection rule." 30

Some of the states were willing to accept the automatic perfection rule. ${ }^{31}$ Some refused altogether to sanction the use of an afteracquired property clause in chattel mortgages. ${ }^{32}$ The majority of states arrived at an intermediate position hereinafter referred to as the "Massachusetts rule." ${ }^{33}$ Under the Massachusetts rule, a chattel mortgage with an after-acquired property clause created a valid and enforceable lien between the parties (mortgagor and mortgagee), but the lien was unperfected as to third parties until the mortgagee took possession of the future property or until the execution of a supplemental mortgage. Any levying of lien creditor or purchaser intervening before the mortgagee took possession could prevail over the mortgagee.

The mortgagee in a Massachusetts-rule state was also said to have an "equitable lien." However, it must be emphasized that the "equitable lien" in automatic-perfection states is not the same as the "equitable lien" in states subscribing to the Massachusetts rule of perfection. The former is equitable in name only, for it is for all other purposes as fully

30 It has also been referred to as the "equity rule." Cohen \& Gerber, supra note 21, at 638. The rule was stated by Pomeroy: "It is well settled that an agreement to charge, or to assign, or to give security upon, or to affect property not yet in existence, or in the ownership of the party making the contract, or property to be acquired by him in the future, although . . . it creates no legal estate or interest in the things when they afterwards come into existence or are acquired by the promisor, does constitute an equitable lien upon the property so existing or acquired at a subsequent time, which is enforced in the same manner and against the same parties as a lien upon specific things existing and owned by the contracting party at the date of the contract." 3 PoMeroy, EQUITY JURISPRUDENCE $\$ 1236$, at 2966 (4th ed. 1918), quoted in Union Trust Co. v. Townshend, 101 F.2d 903, 909 (4th Cir. 1939). The position is similar to that taken by Professor Cook in The Alienability of Choses in Action, 30 HARv. L. REv. 449 (1917). Cook emphasized that the term "equitable" often embraces jural relations which are "concurrently legal and equitable, i.e., recognized and sanctioned both by common law and by equity." Id. at 455.

31 The jurisdictions which adhered to the automatic perfection rule as against at least some third parties were listed by Cohen and Gerber in 1939 as Alabama, Arizona, Iowa, Michigan, Minnesota, New Jersey, North Carolina, South Carolina, Texas, Utah, Virginia, West Virginia and Wyoming. Cohen \& Gerber, supra note 21 , at $638 \mathrm{nn} \cdot 15-17$. The author has not made an exhaustive independent study of the states and therefore cannot assure that the list is complete or current. Certainly New Mexico should be added. Joe Heaston Tractor \& Implement Co. v. Claussen, 59 N.M. 486, 287 P.2d 57 (1955).

32 See Whiteside v. Rocky Mountain Fuel Co., 101 F.2d 765, 769-70 (10th Cir. 1938), aff'd on rehearing, 101 F.2d 771, 771-72 (10th Cir.), cert. denied, 307 U.S. 640 (1939) (court does recognize equitable lien on after-acquired property). See note 50 infra.

33 Following the Massachusetts rule were Connecticut, Illinois, Kansas, Maine, Massachusetts, Nebraska, New Hampshire, Ohio, Rhode Island, Vermont, and Wisconsin. Cohen \& Gerber, supra note 21, at 639 nn.19-22. See note 31 supra. Other states followed a combination of the two rules. E.g., in New York the Massachusetts rule applies to intervening lien creditors, who can prevail over the mortgagee by establishing their lien before the mortgagee takes possession. Rochester Distilling Co. v. Rasey, 142 N.Y. 570, 37 N.E. 632 (1894). But the recorded mortgage on after-acquired property is automatically perfected against subsequent purchasers, who take subject to the lien. Kribbs v. Alford, 120 N.Y. 519, 24 N.E. 811 (1890). 
effective as any legal consensual lien of a mortgage of presently owned property. The latter is something less than this, being equitable in the sense that it lacks the full validity that would be needed to defeat intervening legal lien creditors. It is something in the nature of an imperfect or defective lien, giving the mortgagee "some," but not "full" rights in the property. ${ }^{34}$ Without some further act by the mortgagee, the lien on the future property is not perfected.

\section{Section 60 in Its Historical Setting}

Before analyzing the impact of the bankruptcy preference section on after-acquired property clauses, there are two historically significant areas that require exploration. First it is necessary to have an understanding of the development that section 60 has undergone in the past sixty years. Second it is essential to point out some of the differences between the "equitable lien" on after-acquired property discussed above and the "equitable lien" on defective present transfers. A grasp of the problems in these two areas is fundamental to the analysis attempted by this Article.

\section{The Development of Section 60}

For ease of classification section 60 can be regarded as having undergone three states of development: 1898 to 1938, 1938 to 1950, and 1950 to the present.

Under section $60 \mathrm{a}$ of the 1898 act $^{35}$ a preference was defined as a transfer of property by an insolvent debtor for an antecedent debt, thereby enabling a creditor to recover a greater percentage of his debt than other creditors of the same class. The trustee was given the power under section $60 \mathrm{~b}$ to avoid any such transfer made within four months of bankruptcy if the creditor had reasonable cause to believe it was a preference. But section 60 contained no perfection clause to determine the point in time at which the transfer was to be deemed made ${ }^{36}$-a point which is critical when the transfer is by security

34 Cook has pointed out the polyvalence and potential ambiguity of the term "equitable." See note 30 supra. The Massachusetts rule "equitable lien" is not possessed of the same characteristics as the "equitable lien" of the automatic-perfection jurisdictions. Thus the utilization in this context of the rubric "equitable," which, as Cook has warned, fails to indicate adequately all of the attributes of the particular jural relations involved, can only be misleading.

35 Act of July 1, 1898, ch. 541, $\$ 60(\mathrm{a}), 30$ Stat. 562.

36 See 3 COLLIER, BANKRUPTCY $\$ 60.37$, at $877-78$ (14th ed. 1956) [hereinafter cited as Collier], Moore \& Countryman, Debtors' and Creditors' Rights 800-01 (1951). 
instrument such as a mortgage. ${ }^{37}$ Thus, a mortgagee could withhold his interest in the mortgagor's property from the record until the eve of bankruptcy and still escape the thrust of the preference challenge; in the meanwhile third parties would be misled by the appearance of a sound credit status of the mortgagor. Because the secrecy of the transaction was prejudicial to the general creditors of the debtor, Congress sought to make explicit that this situation would be treated as a preference.

However, in subsequent amendments ${ }^{38}$ the statutory language employed fell short of accomplishing its aim, although the legislative objective was perfectly clear: "This proposed amendment squarely and clearly makes the date of the recording (where recording is required under state law to make the lien valid as against levying creditors) the date at which the [levying] creditor is to prove the existence of all the elements of a preference. . . ." 39 The courts, failing to look to the legislative history, held many eve-of-bankruptcy recordations to be nonpreferential, ${ }^{40}$ stating that although section 60 made clear that the four month period began running from the date of recordation, all the elements of a preference-and, more specifically, the antecedence of the mortgagee's consideration-were to be determined as of the date of the execution of the mortgage. ${ }^{41}$

It was not until 1938 that Congress was able to frame an effective perfection clause. This version ${ }^{42}$ provided that a transfer was to be deemed made when it became so far perfected under state law that no bona fide purchaser from the debtor could obtain rights in the property superior to those of the secured creditor. It is evident that this perfection test required not only that the four month period begin running from the date of perfection (ordinarily recording), but that all the elements of preference be determined as of that time as well. If there was a delay in recording until the eve of bankruptcy, the act of recordation became a transfer for a debt that was then antecedent.

But the 1938 bona fide purchaser test proved unsatisfactory also. This time the pendulum had swung too far, for now all inventory

37 Assume, for example, a mortgage executed at time $\mathrm{X}_{1}$ for a contemporaneous consideration, but not recorded until time $\mathrm{X}_{2}$, on the eve of bankruptcy of the mortgagor. This early $\S 60$ did not require that time $\mathrm{X}_{2}$ be the date at which the transfer was to be deemed made. Hence the courts held that the mortgage was not preferential even though at $\mathrm{X}_{2}$, when it was first perfected, the debt was antecedent.

38 Act of Feb. 5, 1903, ch. 487, §13, 32 Stat. 799; Act of June 25, 1910, ch. 412, $\S 11,36$ Stat. 842; Act of May 27, 1926, ch. 406, \$14, 44 Stat. 666.

39 S. REp. No. 691, 61st Cong., 2d Sess. 8 (1910), concurring in H.R. Rep. No. 511, 61st Cong., 2d Sess. (1910).

40 See 3 Coliter $\$ 60.37$, at 878-84.

41 Ibid. See also Moore \& Countryman, op. cit. supra note 36 , at 801-02.

42 Act of June 22, 1938, ch. 575, §1, 52 Stat. 869. 
transactions were subjected to the risk of being set aside as preferences. Since effective financing by secured transactions covering goods held for resale must permit the debtor to sell the property to a purchaser free of encumbrances, the secured interest in such property could never be perfected as against bona fide purchasers. The unperfected interest would therefore be inevitably preferential if all the other requisite elements were present. ${ }^{43}$ To rectify this situation, the 1950 amendment to section 60 was enacted. ${ }^{44}$

Under the 1950 amendment ${ }^{45}$ the bona fide purchaser test was replaced with a lien creditor test of perfection for all personal property transfers. Thus the present status of section 60 is that transfers of personalty that are perfected under state law as against any subsequent lien creditor are perfected as against the trustee in bankruptcy. All the elements of a preference are determined at, and the four month period begins running from, such date of perfection.

At this stage it is well to point out that one evil which the legislators sought to eliminate by the amendments was the secret unrecorded mortgage on presently owned property. ${ }^{46}$ But there was another object too that drew the legislative fire: this was the problem of the secret equitable lien. As already observed, "equitable lien" labels were attached to after-acquired property transactions by both Massachusetts and automatic perfection rules. But the equitable lien also arose in the context of the defective transfer of presently owned property. It is to the problem of the ubiquitous equitable lien in bankruptcy that this analysis now turns.

\section{Equitable Liens}

The equitable lien on transfers of personalty has been found by judicial construction in so many different situations that it has become

43 Discussions of the impact of the bona fide purchaser test on inventory transactions have been numerous. See 3 CollIER $\$ 60.38$, at 904; Moore \& Tone, supra note 16; Oglebay, Proposed Revision of Section 60a of the Bankruptcy Act: A Step Backzuards, 51 Commercial L.J. 263 (1946); Comment, 57 Y YLE L.J. 828 (1948).

44 There is no intention here to underestimate the impact of Corn Exchange Nat' Bank \& Trust Co. v. Klauder, 318 U.S. 434 (1943). The Supreme Court there invalidated a non-notification assignment of accounts receivable which was deemed unperfected under Pennsylvania law. Because many jurisdictions followed the Pennsylvania rule requiring notification of assignment to perfect, bona fide assignment transactions were jeopardized by the court's preference finding. Agitation for amendment to $\S 60$ followed this case. But since most states circumvented the thrust of Klauder by passing non-notification and other statutes, there was little real need for an amended $\$ 60$ in this area. For a comprehensive treatment of the Klauder case and its implications see Comment, 67 YALE L.J. 402 (1958).

4564 Stat. 24 (1950), 11 U.S.C. \$ 96 (a) (1958).

46 There can be no doubt that the element of secrecy was strongly influential in directing much of the legislation: "the long history of $\S 60$ gave evidence of repeated legislative attempts to strike down what might well be termed 'secret transfers' by the debtor-that is, transfers executed but not disclosed by recordation registration, change of possession, or the like, so that other creditors were not apprised . . .." Oglebay, sipra note 43 , at 263. 
a catch-all term that does not lend itself to accurate definition. ${ }^{47}$ The equitable lien arose most typically in situations where there were contracts to mortgage but where no mortgage had in fact been executed; ${ }^{48}$ or where a mortgage had been executed defectively and was never corrected, therefore not qualifying for recordation; ${ }^{49}$ or where there was a contractual agreement providing for security upon some property that could not be embraced by a chattel mortgage or some other legally sanctioned security instrument. ${ }^{50}$ These equitable liens, although never fully perfected as against bona fide purchasers, were often held to be superior to the rights of subsequent lien creditors: ${ }^{51}$ the lien was said to "relate back" to the date of the execution of the instrument creating it.

In Sexton $v$. Kessler, 52 a classic case involving an equitable pledge, the debtor segregated some corporate securities in his vault and earmarked them as collateral securing a loan made by a creditor. The creditor was notified that the collateral had been segregated, but the debtor did not at that time part with possession. Within the four month period before bankruptcy the creditor took possession and the trustee sued to set aside this transfer as a preference. The United States Supreme Court, applying New York law, said that the agreement between the parties gave rise to an equitable pledge, and that the creditor (equitable pledgee) was entitled to possession of the property. The Court stated: "[A] general promise to give security . . . is not enough. . . . [But this agreement] purported not to promise but to transfer; and the subject-matter was not goods and chattels in the sense of the New York mortgage law as we understand that law to be interpreted . . . ." 53 Therefore the agreement did not have to be

47 See In re Interborough Consolidated Corp., 288 Fed. 334, 349 (2d Cir.), cert. denied, 262 U.S. 752 (1923), where the court comments upon the fact that the term is "intensely undefined." For collection of cases and discussion of the impact of "equitable liens" on presently owned property see 3 COLLIER $\$ 60.37$, at 885-90. Cf. Britton, Equitable Liens-A Tentative Analysis of the Problem, 8 N.C.L. Rev. 388 (1930); Comment, 57 Yale L.J. 828 (1948).

48 E.g., Porter v. Searle, 228 F.2d 748 (10th Cir. 1955).

493 CoLliER $\$ 60.37$, at 886 .

50 "Considering the nature of an equitable lien, how it may be created and its constituent elements, it would be difficult indeed to conceive how the chattel mortgage act could be complied with by the holder of such equitable lien. The chattel mortgage act requires that the mortgage itself, the physical document, shall be filed or recorded. True, a written statement of the facts that go to constitute an equitable lien could be made, a verification of the truthfulness thereof attached, and as thus made up it could be filed with the county clerk and recorder, but no intention to require that such action be taken can be deduced from the chattel mortgage act, or any Colorado statute" Whiteside v. Rocky Mountain Fuel Co., 101 F.2d 765, 769 (10th Cir. 1938), aff'd on rehearing, 101 F.2d 771 (10th Cir.), cert. denied, 307 U.S. 640 (1939).

51 Comment, 57 Y ALE L.J. 828, 839 (1948).

52225 U.S. 90 (1911).

53 Id. at 98 . 
recorded as a chattel mortgage, and possession was all that was needed to perfect the equitable pledge, which then related back to the date of the agreement. The Court concluded that the taking of possession was non-preferential: "When the [creditor] . . . took the securities it only exercised a right that had been created long before the bankruptcy and in good faith." 54

The equitable pledge lacked notoriety in that it could not, of course, be recorded; failure to transfer the collateral at the time of the agreement prevented it from being a legally perfected pledge. These secret equitable liens, like the unrecorded but otherwise valid mortgage transfers discussed above, were felt by Congress to present the evils of preferences, and the 1938 amendment sought to eliminate them. Since an equitable lien on present goods would not prevail over a bona fide purchaser, the 1938 bona fide purchaser test overcame the nemesis of the defective equitable lien.

When the 1950 amendment was passed to rectify the undesirable severity of the 1938 test, the legislators, not wanting to revive the equitable lien and relation back doctrines, ${ }^{55}$ inserted section $60 \mathrm{a}(6)$ which provides:

"The recognition of equitable liens where available means of perfecting legal liens have not been employed is declared to be contrary to the policy of this section. If a transfer is for security and if (A) applicable law requires a signed and delivered writing, or a delivery of possession, or a filing or recording, or other like overt action as a condition to its full validity against third persons other than a buyer in the ordinary course of trade claiming through or under the transferor and (B) such overt action has not been taken, and (C) such transfer results in the acquisition of only an equitable lien, then such transfer is not perfected within the meaning of [section $60 \mathrm{a}(2)] . . . "$

The legislative history and the background of the 1938 and 1950 amendments clearly indicate the evils at which the legislation was directed. Two of these have been discussed: the unrecorded mortgage and the agreement creating an equitable lien on presently owned property. A third was the chattel mortgage with an after-acquired property clause in a Massachusetts-rule state, for this clause also created an unperfected "equitable lien" which required the doctrine of relation back to protect it in bankruptcy. ${ }^{56}$

$54 I d$. at 99.

55 "The objectives of . . the bill are as follows: (A) To retain unimpaired the basic object of the 1938 amendment, which eliminated the 'relation back' doctrine of Sexton v. Kessler . . . ." H.R. REP. No. 1293, 81st Cong., 1st Sess. 6 (1949).

56 It should be emphasized here that automatically perfected after-acquired property liens, unlike Massachusetts-rule liens, were not unperfected: these former 
Preference Attack on the After-Acquired Property Clause

Within this framework of the preference history and the concepts of after-acquired property and equitable liens, the treatment of the after-acquired property clause in bankruptcy must be explored in detail.

\section{The Massachusetts Rule-Pre-1938}

Under the pre-1938 section 60 , the trustee's contention that taking possession of after-acquired property within four months of bankruptcy constituted a preferential transfer for an antecedent debt was generally unsuccessful. Two early Supreme Court cases provided the precedent in the field. In Thompson v. Fairbanks ${ }^{57}$ the debtor executed for contemporaneous consideration a mortgage covering his stock in trade presently owned and to be thereafter acquired. The mortgagee recorded the instrument in full compliance with Vermont law more than four months before the mortgagor became a bankrupt, but did not take possession of the goods until the eve of bankruptcy. The trustee sued to recover the goods or their value, contending that the after-acquired goods were transferred for a then antecedent debt. The Court, finding that there was no fraud and that recordation had been effected, asserted:

"So in this case, although there was no actual existing lien upon this after-acquired property until the taking of possession, yet there was a positive agreement, as contained in the mortgage and

so-called "equitable liens" were never subject to defeat by third parties provided the original instrument was formally perfected. The legislative history nowhere gives any indication that such liens were to be eliminated or struck down as preferences. See notes 100-03 infra and accompanying text. Admittedly where there was an agreement creating an automatically perfected equitable lien on future property which yet remained unrecorded, then the transaction would seem to fall within the purview of the post-1938 $\$ 60$ (see Whiteside v. Rocky Mountain Fuel Co., 101 F.2d 765 (10th Cir. 1938), aff'd on rehearing, 101 F.2d 771 (10th Cir.), cert. denied, 307 U.S. 640 (1939)) for such a transaction, although valid under the pre-1938 act, is certainly prejudicial to the general creditors. It may be assumed that this device was another of the evils aimed at by the 1938 amendment. But, it bears repeating, the evil consists precisely in a lack of notoriety, and where the agreement is recordable and recorded, there would seem to be no preference problem even under the bona fide purchaser test of the $1938 \S 60$. Without notoriety, of course, a bona fide purchaser can prevail; it is the lack of notice that makes him bona fide. With regard to the 1938 and proposed 1950 amendments it has been asserted that "certainly the creditor who fully obeys local law by providing the world with notice of his interest in the debtor's property is not the person against whom Section 60 is aimed." Comment, 57 Y ALE L.J. 828, 835 (1948). See also Moore \& Tone, supra note 16, at 698: "Recently the fear has been expressed that the bona fide purchaser test will enable the trustee to invalidate properly filed or recorded trust receipts, factor's liens, chattel mortgages on goods held for resale and similar legitimate security devices. - Section $60 \mathrm{a}$ should be interpreted in the light of its legislative history as striking at secret liens, previously protected by the doctrine of 'relation back,' not at legitimate security devices which have been given the full notoriety prescribed by state law, and which, by their very function, are designed to enable the debtor to have possession and the power of sale and hence are never perfectible as against the ordinary purchaser."

57196 U.S. 516. (1905). 
existing of record, under which the inchoate lien might be asserted and enforced . . . [and it] related back to the time of the execution . . . as it was only by virtue of that mortgage that possession could be taken." 58

In Humphrey v. Tatman, ${ }^{59}$ decided the same year, the Court reaffirmed its holding in Thompson. Here also the mortgage contained an after-acquired property clause, but was not recorded when executed. Being unrecorded, the mortgage was voidable by any lien creditor intervening before possession was taken; the mortgagee, however, took possession on the eve of bankruptcy before any creditors intervened. The Court held that just as possession would prevail over creditors with respect to the presently owned goods, it would likewise prevail over creditors with respect to the after-acquired goods. The elements of a preference were to be determined at the time the mortgage was executed, and the doctrine of relation back operated to perfect the lien as of that time. The Court had assumed, "also, without deciding, that if, as against the trustee, the mortgage is to be regarded as first having come into being when the mortgagee took possession, it would be void." 60

The net effect of the Court's holding in each case is that in Massachusetts-rule states, where the transfer of property under an afteracquired property clause is unperfected without some further action being taken, ${ }^{61}$ the relation back doctrine is essential and its invocation is effective to insulate the lien on the future property from the trustee's attack. And this doctrine is not confined to the financing of tangible property; it applies as well to the assignment of accounts receivable. In In re Robert Jenkins Corp. ${ }^{62}$ the assignment provided in part, ". . . we herewith pledge the accounts receivable as may appear on the ledgers . . . at any time, without reserve . . . ." Account debtors were not notified of the assignment and the debtor was permitted to collect and apply the proceeds to his own use, so that at the time of his bankruptcy the only accounts outstanding were those that arose subsequent to the date of the agreement. But on the eve of bankruptcy

$58 I d$. at 524.

50198 U.S. 91 (1905).

${ }^{60} \mathrm{Id}$. at 92 . This case is representative of two separate evils: lack of notoriety of the original mortgage and imperfection of the equitable lien until the mortgagee had taken possession of the future goods.

61 In Massachusetts-rule states the after-acquired property clause is often said to create an "equitable pledge." "In the absence of statute, the after-acquired property clause in a mortgage of inventory also is usually viewed as creating an equitable pledge, under which the mortgagee is entitled to protect his claim of lien by taking possession of the after-acquisitions . . .." Everett, Securing Security, 16 LAW \& Contemp. Prob. 49, 55 (1951).

6217 F.2d 555 (1st Cir.), cert. denied, 257 U.S. 527 (1927). 
a schedule of the outstanding accounts was delivered to the creditor. The trustee argued that the whole transaction was fraudulent under the doctrine of Benedict $v$. Ratner. ${ }^{63}$ But the court found that the Benedict doctrine was inapplicable in Massachusetts, and that there was no preferential transfer-following the reasoning of Thompson and Humphrey. The original agreement created a security interest in the nature of equitable title in the future accounts, which equitable title ripened into a fully perfected legal title by virtue of the delivery of the schedule of accounts. The act of delivery created a legal lien which related back to the date of the agreement at which time there were none of the elements of a preference. Of course, if the mortgagee seized the afteracquired goods after the petition in bankruptcy was filed, he lost his equitable lien by virtue of its being unperfected at a time when the trustee acquired the power of an intervening lien creditor. ${ }^{64}$

\section{The Automatic Perfection Rule-Pre-1938}

A paucity of cases dealing with the automatic perfection rule in the context of section 60 makes analysis in the area difficult. One can speculate as to the reasons for this paucity: the Benedict and fraud doctrines of accounts receivable and inventory financing may have given bankruptcy trustees easier means of setting aside the secured transactions; a presumption of validity existed in the states where the issue might have arisen; and, of course, only a few states followed the automatic perfection rule.

There were no pre-1938 Supreme Court cases challenging as preferential a transfer under an after-acquired property clause in a chattel mortgage executed in an automatic-perfection state. In 1907, however, in Union Trust Co. v. Bulkeley ${ }^{65}$ the Sixth Circuit decided a case that has implications bearing on the issue. Here the creditor endorsed notes for the debtor, receiving back an assignment of all present and future accounts receivable. The following year the debtor became a bankrupt and the trustee collected all moneys due and owing under the then outstanding accounts receivable. The creditor-assignee sued to recover the moneys collected. The court's opinion does not detail the defense of the trustee, but certainly a preference argument would have been likely under the circumstances. The court held, how-

63268 U.S. 353 (1925). When a case involving after-acquired property runs afoul of the Benedict rule, there is never any discussion of the preferential transfer aspects of the case. The court declares the transfer void under the fraud-in-law doctrine. For illustrative cases see In re Turley, 92 F.2d 944 (7th Cir. 1937); In re Steele, 122 F. Supp. 948 (E.D.N.C. 1954) ; In re Streeter, 20 F.2d 157 (D.N.H. 1927).

64 In re Hurley, 185 Fed. 851 (D. Mass. 1910).

65150 Fed. 510 (6th Cir. 1907). 
ever, that in the absence of fraud the common law of Michigan recognized, in equity, the assignment of accounts receivable in the future. "It is true that the subject to be affected by it [the lien] was to be thereafter acquired; but, when acquired, it would become subject to the lien without any new or further agreement. This is something quite different from an executory contract." 66 It is apparent from the opinion ${ }^{67}$ that the lien on future accounts created by the original assignment was equitable in name only. There was no gap in time during which the accounts were unencumbered, and the lien at all times had the force and effectiveness of a legal lien, without possession ever having been taken.'

In In re Alabama Braid Corp. ${ }^{68}$ a debtor had executed a mortgage on all his presently owned property and any property to be acquired thereafter in the ordinary course of business except property held or to be held for resale. The mortgage was properly recorded. Several years later on the eve of the debtor's bankruptcy and at a time when the mortgagee knew of the debtor's insolvency, the debtor executed a supplemental mortgage covering the property acquired subsequent to the date of the original mortgage. This too was recorded. The trustee sued to set aside this supplemental mortgage, apparently alleging it to be a preference. ${ }^{69}$ The court found that the supplemental mortgage was avoidable under the Bankruptcy Act, but held that the original mortgage, nevertheless, was sufficient to perfect a lien upon all of the present and future property. The court stated:

"[A] chattel mortgage covering after-acquired property operates as a present contract which attaches when the property is acquired or comes into existence, and makes it in equity an effective security for the debt provided for in the mortgage. Courts of equity will protect and enforce such equitable title against all but bona fide purchasers thereof for value without notice. It is not necessary, in order to perfect such equitable title, that any additional mortgage be executed or that the mortgagee take possession of such property after the same is acquired by the mortgagor. Any holder of the legal title to such property, with notice of such equitable title, holds such legal title as trustee for the holder of such equitable title.

And earlier in its opinion the court wrote: "Under the law of Alabama, the filing for record in that county in which the property is to be ac-

66 Id. at 516. (Emphasis added.)

67 Compare In re Hurley, 185 Fed. 851 (D. Mass. 1910). See also the opinion of the district court quoted in full in the circuit court report. 150 Fed. at 511-15.

6813 F. Supp. 336 (N.D. Ala. 1935).

69 Although the opinion does not explicitly state the trustee's contention, the court speaks in terms of present and past consideration and knowledge of insolvency.

7013 F. Supp. at 339 . (Emphasis added.) 
quired of a chattel mortgage covering after-acquired property constitutes notice of such mortgage from the date the same is filed for record." 71 Thus what the court characterizes as an "equitable lien" it recognizes, by virtue of the constructive notice attaching by state law to recordation, as a legal lien: one binding immediately and without further action upon all supervening third parties. There was no need to invoke a relation back doctrine because the lien became a continuing one, perfected from the time the original mortgage was recorded. This case is truly exemplary of the fact that the use of the term "equitable lien"-apparently a throwback to the old common-law restrictions on financing against after-acquired property-can be misleading. It cannot be emphasized too strongly that there are significant differences between the so-called "equitable lien" of the Alabama Braid case and the "equitable lien" of the Thompson case.

In In re Comet Textile, ${ }^{72}$ a case decided under section 45 of the New York Personal Property Law, the court did not employ "equitable lien" language; it focused clearly upon the effect of the lien. Section 45, the Factors Lien Law, had been passed to offset the difficulty and complexity of financing against inventory. The act provided, inter alia, for a continuing lien on all present and future inventory goods if certain statutory requirements of perfection were met. In the Comet case the creditor-factor had advanced money to the bankrupt and had entered into a factoring agreement which was fully perfected under the act. Within four months of the debtor's bankruptcy the factor seized the goods, and the trustee sued to set aside the transfer of the after-acquired property as a voidable preference. The court held that the lien on the goods was perfected at the date of the agreement, and that possession was not needed to perfect. The factors lien is a continuing, perfected, non-possessory legal lien: "It follows that the lien is good against creditors with claims antedating the notice, unless such claims have been made liens attaching to the merchandise prior to filing of notice." 73

Comet has significance for the automatic perfection classification of after-acquired property cases because it makes explicit that this statutory lien is in all respects and from the moment of perfection a fully perfected legal lien, despite the fact that future property is involved. This is especially significant since, unlike Massachusetts, New York had never had a relation back doctrine on after-acquired property financing through a chattel mortgage. Although New York had followed

TI Ibid.

7215 F. Supp. 963 (S.D.N.Y. 1936), aff'd per curiam, 91 F.2d 1008 (2d Cir. 1937). 73 Id. at 964. 
the Massachusetts rule of perfection as to creditors, it did not develop a doctrine of relation back to protect the mortgagee in bankruptcy, ${ }^{74}$ but confined the relation back doctrine to unperfected equitable liens on presently owned property.

\section{The Massachusetts Rule-Post-1938}

The 1938 amendment to section 60 changed drastically the treatment of after-acquired property clause transfers in Massachusetts-rule states having the relation back doctrine. The effect of the 1938 amendment is spelled out clearly in In re Markert, ${ }^{75}$ where the debtor executed a mortgage of present and future inventory and present and future accounts receivable. Two days before the bankruptcy of the debtor, the mortgagee-assignee took possession of the goods, some of which were acquired subsequent to the date of the mortgage. The precise issue in the case was determination of when the transfer of afteracquired property occurred. In finding the transfer preferential as to goods, the court reasoned, first, that the after-acquired property clause created an equitable lien which was not perfected as to bona fide purchasers until two days before bankruptcy, thereby becoming a transfer for a then antecedent debt; and, second, that the 1938 amendment had eliminated the relation back doctrine that Massachusetts had heretofore recognized. As to the future accounts receivable, the court found that the lien on them was unperfected until the accounts were segregated and assigned specifically to the mortgagee-assignee, ${ }^{76}$ at which time they were transferred for an antecedent debt and thereby preferential. This case, dealing as it does with both accounts receivable and tangible chattels, is the direct sequel to the Humphrey and Jenkins cases of the pre-1938 era. It establishes that the amendment has accomplished what the legislators intended: capture of the unperfected equitable lien which under the relation back doctrine had escaped section 60 in the Massachusetts-rule jurisdictions. ${ }^{77}$

The 1950 amendment, which utilized a lien creditor test and isolated the equitable lien problem in a separate clause, did not change the result of the Markert case. The reasoning of that case would still apply

74 For a discussion of the status of New York law on after-acquired property see Goldstein v. Rusch, 54 F.2d 86 (S.D.N.Y. 1931), modified, 56 F.2d 10 (2d Cir.), cert. denied, 287 U.S. 604 (1932). See also Irving Trust Co. v. Commercial Factors Corp., 68 F.2d 864 (2d Cir. 1934).

7545 F. Supp. 661 (D. Mass. 1942).

76 There were some future accounts that had been assigned specifically prior to the four month period preceding bankruptcy and these were considered perfected.

77 Accord, Rosen v. Haines-ce Brook, Inc, 52 F. Supp. 791 (D. Mass. 1943). 
under section $60 \mathrm{a}(2),{ }^{78}$ since the lien on after-acquired property would be subject to defeat not only by bona fide purchasers but also by intervening lien creditors. Furthermore section $60 \mathrm{a}(6)$ specifically makes its own more stringent buyer-in-the-ordinary-course-of-trade test applicable to "equitable liens," and similarly eliminates the relation back doctrine.

A recent decision in Illinois, a state which follows the Massachusetts rule, substantiates this conclusion. In Curtis v. Knox ${ }^{79}$ a creditor made a loan to the debtor three years prior to his bankruptcy and the creditor took back a mortgage on identified machinery. The mortgage contained an after-acquired property clause. Within four months preceding bankruptcy the mortgagee foreclosed on the machinery, all of which had been acquired prior to the four month period. The trustee sued to recover the value of the after-acquired machinery sold at the foreclosure sale, claiming that the foreclosure proceedings effected a preferential transfer. The mortgagee contended that an after-acquired property clause in Illinois creates a lien perfected automatically when the mortgagor acquires the property and that his lien was therefore perfected prior to the eve of bankruptcy. The court held, however, that an after-acquired property clause creates only a legally defective equitable lien that is not perfected until possession is taken. The foreclosure action was equivalent to possession, but at that time it constituted a transfer for an antecedent debt. The act of perfecting was deemed to be the making of a transfer.

\section{The Automatic Perfection Rule-Post-1938}

Although the 1938 and 1950 amendments have made transfers of after-acquired property subject to attack as preferences in Massachusetts-rule states, it is submitted that these amendments have not had the same result in states following an automatic perfection rule. Although neither of two cases found involving chattel mortgages under the amendments-both decisions governed by the 1950 version-directly discussed the problem of the preferential transfer, there is significance in the fact that the issue was not treated, since certainly, if section 60 was thought to apply, a preference would have had to be found in each case.

78 "[A] transfer of property other than real property shall be deemed to have been made or suffered at the time when it became so far perfected that no subsequent lien upon such property obtainable by legal or equitable proceedings on a simple contract could become superior to the rights of the transferee. ..." Section $60 \mathrm{a}(2)$.

79254 F.2d 433 (7th Cir. 1958). Accord, in Massachusetts, Matter of Super Value Mkt, 151 F. Supp. 639 (D. Mass. 1957). 
In Joe Heaston Tractor \& Implement Co. $v$. Claussen ${ }^{80}$ a seller of merchandise obtained a mortgage on the buyer's stock in trade, including after-acquired property. The mortgage was recorded prior to buyer's bankruptcy but seller never took possession of the goods; after bankruptcy had supervened he sued the trustee to recover their value. The court found for the seller-mortgagee and wrote: "there can be no question of the validity of a chattel mortgage as against subsequent creditors, on a stock of merchandise left with the mortgagor for sale in the ordinary course of trade, from the time of its filing for record." 81 The court held that while any property acquired subsequent to the execution of the mortgage but prior to recordation was not to be considered liened, the other after-acquired property was liened automatically and the mortgagee was entitled to recover its value from the trustee. Yet, certainly if the case had arisen in a Massachusetts-rule state, the lien on the after-acquired property could never have stood up as against the trustee, even under the pre-1938 status of section $60 .{ }^{82}$ The court did not discuss equitable liens or anything remotely connected with antecedent debt or relation back.

In In the Matter of Hayes ${ }^{83}$ the Reconstruction Finance Corporation claimed a secured lien in bankruptcy as mortgagee of, among other things, some equipment of the bankrupt. The recorded mortgage had an after-acquired property clause; the property in dispute was future property of which the creditor had not taken possession. The court found that the chattel mortgage statute sanctioned after-acquired property clauses. The lien of the mortgage attached to the subsequent acquisitions "immediately upon the same coming into the possession of, or under the control of the mortgagor, subject to all valid prior liens, claims, titles, and encumbrances." " 84 The original recordation provided constructive notice to all the world ${ }^{85}$ and the lien was perfected continuously from that time. Thus, despite the failure of the secured creditor to take possession, he was held to have a superior lien on the future property.

There is, moreover, a case-decided under the 1938 act-which by its interpretation of the Factors Lien Act of New Hampshire adds considerable support to the thesis of this paper that automatically perfected liens are not preferential transfers. Manchester Nat'l Bank $v$.

8059 N.M. 486, 287 P.2d 57 (1955).

81 Id. at 487, 287 P.2d at 59. (Emphasis added.)

82 See text accompanying notes 61-64 supra.

83140 F. Supp. 444 (D. Alaska 1956).

$84 \mathrm{Id}$. at 446.

85 "There is no provision of the Alaska statutes requiring re-filing of a chattel mortgage to cover after-acquired property . . ." Id. at 447. 
Roche ${ }^{86}$ is a post-1938 companion case to the pre-1938 Comet decision that comes to the same conclusion as Comet despite the amendment to section 60 . It is significant not merely for its result, but also for its rationale and for the legislative developments that it seems to have influenced. In Roche there was a factoring agreement between the debtor and the factor, who complied with all the requirements for perfecting the lien at the date of the agreement. Included within the collateral liened were all accounts receivable presently owned and to be acquired and, of course, the present and future inventory. Less than four months before he became a bankrupt the debtor notified the account debtors that their accounts were assigned to the factor. Despite the factor's contention to the contrary, the court said that the Factors Lien Act did not contemplate a general assignment of future accounts in presenti at the date of the factoring contract; further action was needed for perfection of the lienor's interest in the accounts. But no such action was required for perfection of the future additions to inventory; in effect the Massachusetts rule was applied to accounts and the automatic perfection rule to goods. The court found the basis for its distinction within the language of the statute:

"[I]t is not without significance that . . . the New Hampshire legislature specifically provided that the lien on merchandise would be valid from the time of filing the prescribed notice 'whether such merchandise shall be in existence at the time of the agreement creating the lien or at the time of filing such notice or shall come into existence subsequently thereto or shall subsequently thereto be acquired by the borrower.' In other words, the res which is the subject of the lien provided in $\S 1$ is the merchandise or stock in trade, conceived of as a unit presently and continuously in existence - a 'floating mass,' the component elements of which may be constantly changing without affecting the identity of the res. . . . So conceived, it is not inconsistent with the existence of the lien or floating charge on the inventory, as it may be made up at any particular time, that the borrower is free to withdraw an item from stock for sale in the regular course of business, without any obligation to account to the lien holder for the proceeds. . . . By analogy it might be possible to treat a merchant's accounts receivable as a unit presently and continuously in existence, the competent elements of which (the particular accounts) may be constantly changing, without affecting the identity of the res; so that a general assignment by way of security of accounts receivable present and future might be deemed to create in praesenti a lien upon this enduring unit, the accounts receivable, which lien would persist as a floating charge upon such res, however much its component elements might change from time to time by the payment 
of old accounts and the creation of new ones. But when the legislative explicitness in $\S 1$. . is contrasted with the language of $\S 5$, it would be quite far-fetched to read into $\S 5$ any such sophisticated concept as suggested above." 87

Several months after the decision the New Hampshire legislature amended the Factors Lien Act to provide for just such a general assignment of accounts receivable. ${ }^{88}$ Today both inventory and accounts receivable are treated alike when utilized as collateral under the Factors Lien Act. ${ }^{89}$

The court in Roche speaks in terms of a continually existing res which is presently assigned and the components of which are in a constant state of change as new units are substituted for old units. This "sophisticated concept" may differ somewhat from the notion of automatic lien perfection on a future chattel or account under a chattel mortgage with an after-acquired property clause, but there are strong similarities. The lien under either concept dates from the original perfection with no gaps during which any creditor can intervene. ${ }^{90}$ And such a case arising under the Factors Lien Act is a particularly appropriate authority in attempting to predict the judicial treatment of article 9 transactions when bankruptcy intervenes. The floating lien sanctioned by the Code is derived in large part from the inventory and accounts receivable financing provisions of the Factors Lien Acts; ${ }^{91}$ the Code has expanded the reach and scope of this floating lien to allow the encumbrance of virtually all personal property. ${ }^{92}$

87 Id. at 831.

88 N.H. Rev. Stat. AnN. \$ 446:7 (1955).

$89 \mathrm{It}$ is interesting to note that the Factors Lien Act, despite the language of "continuing lien," could have been interpreted to create something in the nature of a Massachusetts-rule lien. The act uses language to the effect that the lien shall exist upon all property "from time to time consigned to or pledged with" the factor. This language could have been construed to require periodic statements to perfect the after-acquired property. But in Colbath v. Mechanicks Nat'l Bank, 96 N.H. 110, 70 A.2d 608 (1950), the New Hampshire Supreme Court followed the Comet case and declared that this language did not require any consignment or further act of transfer to perfect.

80 The Factors Lien Act was designed to give prospective secured creditors a safer means of financing than had previously existed under the chattel mortgage act. New Hampshire had been a Massachusetts-rule state under chattel mortgage financing and therefore a secured creditor using the mortgage always ran the risk of losing out to an intervening creditor. The New Hampshire Supreme Court has recently commented upon this development. Haskins v. Dube, 101 N.H. 224, 138 A.2d 677 (1958).

91 See UCC \&9-204, comment 3. The following 26 states now have Factors Lien Acts : Alabama, Connecticut, Delaware, Florida, Georgia, Illinois, Minnesota, Mississippi, Missouri, New Hampshire, New Jersey, New York, Indiana, Maine, Maryland, Michigan, North Carolina, Ohio, Rhode Island, South Carolina, Tennessee, Texas, Vermont, Virginia, West Virginia and Wisconsin. The Massachusetts and Pennsylvania Factors Lien Acts have been replaced by the Code. The Connecticut and New Hampshire Acts will be replaced upon the effective date of the Code in those states. See note 4 supra.

92 UCC $\$ 9-204(4)$ lists the types of future property that cannot be made subject to a security interest. 
The Impact of the Code on Preference Status of AfterAcguired Property Transactions; the Role of

\section{SECTION 9-108}

Given this background, what result may be expected if and when a trustee in bankruptcy challenges as a preference an after-acquired property transfer under the Code?

Code security provisions make it absolutely clear that the first to file notice has a secured claim that prevails over everyone except holders of prior secured claims, ${ }^{93}$ buyers in the ordinary course of business, ${ }^{94}$ and later perfecting holders of purchase money interests in the afteracquired property. ${ }^{95}$ A security interest perfected by filing is considered to be continuously perfected by that notice; ${ }^{96}$ the date of notice determines the time at which priority is established. ${ }^{9 \tau}$ Thus, by filing a notice of intention to engage in a secured commercial transaction the creditor may have his rights of priority pre-date the execution of the security instrument itself. In effect the Code has applied to all permitted afteracquired property transfers rules granting the security interest at least as favorable priority status as that possessed by inventory and accounts receivable transactions under the New York and New Hampshire Factors Iien Acts. The Code's security interest, when perfected, is continuously perfected as to all present and future personalty included in the instrument; it is in all respects a "legal" interest.

What then is the function of section 9-108? This section was designed to remove the perceived problem of the preferential transfer in bankruptcy by providing that the debtor's acquisition of the collateral in the ordinary course of business or under a contract of purchase envisaged by the security instrument will be deemed to effect a transfer for contemporaneous value and not for antecedent debt. But analysis of the background and circumstances surrounding after-acquired property in the bankruptcy context will indicate that for this purpose section 9-108, however desirable its aim, is probably unnecessary and quite possibly self-defeating.

\section{(1) Section 9-108 Is Probably Unnecessary}

If the Roche and Comet cases mean anything, they mean that there can be inventory and accounts receivable financing free from attacks of the trustee in bankruptcy under a financing device that is, for purposes 
of discussion here, similar to that of article 9 of the Code. Since the New York and New Hampshire Factors Lien Acts, then, have met with success in avoiding the preference pitfall, there would seem to be no need for section 9-108. Roche found its rationale in the fact that there was a continuing res and that the lien attached to the res. Comet did not even demand the construction of a res. It turned solely upon the fact that the statute had provided for an automatically perfected lien and that the after-acquired goods became subject to this continuing lien once the original agreement was perfected. This last analysis, particularly, is essentially no different than the construction of the chattel mortgage acts represented in the Alabama Braid, Claussen and Hayes cases; in states with the automatic perfection rule security interests in afteracquired property have escaped preference avoidance even in the absence of specific statutory provision establishing a continuing lien. It is submitted that a court made cognizant of the nature of the Code's continuing and floating legal lien ${ }^{98}$-perfected at the execution and filing of the financing instrument ${ }^{99}$ - should not be able to hold that a preferential transfer has been effected. To find a preference the court would have to take authority either from the legislative history of the 1938 and 1950 amendments or from the present language of section 60 . Neither, however, appears to support such a construction.

\section{Legislative History}

As indicated above, there were several evils at which the section 60 amendments were directed: the equitable lien of the Sexton variety was one; the equitable lien arising out of after-acquired property transfers under the Massachusetts rule was another. In both cases the execution of some supplementary act was by state law necessary to perfect these liens as against third parties, and the doctrine of relation back was essential for their survival in bankruptcy. They were secret liens, unrecorded or unrecordable-or, at the least, liens to whose recordation no statute gave the effect of constructive notice as covering the particular property subsequently coming into the debtor's hands. But the automatically perfected lien on after-acquired property was not thought to be eliminated by the amendments, not, at least, in a state which sanctioned such a transaction on inventory. In hearings before the House Judiciary Committee considering the 1938 amendment, ${ }^{100}$ Professor

98 See UCC $\$ 9-204$, comment 3.

99 UCC $\$ 9-303(1)$.

100 Hearings before the Committee of the Judiciary of the House Studying The Revision of the Bankruptcy Act, 75th Cong., 1st Sess. 123 (1937). 
McLaughlin, ${ }^{101}$ the chief draftsman, testified that a case like Thompson was to be considered a preference under the 1938 act because the lien on the after-acquired property was not perfected. But he asserted that where a state, such as Michigan, ${ }^{102}$ sanctioned a type of floating lien, the 1938 act did not aim at depriving the mortgagee of his secured interest in the future acquisitions. For such a lien there was, first, no relation back and, second, complete perfection of the interest in the after-acquired property. Given these, he reasoned, there was no preference problem. His analysis seemed to focus upon the fact that there was an element of substitution in such a case: ${ }^{103}$ the old goods were replaced by the new and hence not transferred for an antecedent debt.

But the fact that a state provides for automatic perfection of a lien on after-acquired property would seem sufficient reason for coming to the same conclusion. Whenever the original agreement embraces future property, the lien is a continuing one, never defective, never secretive. Just as the continuing lien on inventory shifts from old goods to new, the automatically perfected non-inventory lien immediately reaches out and attaches to each new acquisition. And whereas the lien on afteracquired property in both inventory and non-inventory transactions is always unperfected in the Massachusetts-rule states, it is never unperfected in the automatic-perfection states. But when the 1938 amendment attacked the equitable lien on after-acquired property, it attacked precisely the unperfected lien; there is no discussion in the hearings about making preferential transfers out of the automatically perfected lien. At a minimum the legislative history proves that the floating lien concept on inventory was never deemed to be preferential. It is submitted that the automatic perfection doctrine is in essence a floating lien doctrine allowing the lien to attach to all future acquisitions, whether or not inventory. The use of automatic perfection terminology is only another way of describing a continuously perfected lien that floats to any and all property embraced by the security agreement. It cannot be doubted that the Factors Lien Acts fit squarely within the exemption from preference attack noted by Professor McLaughlin; a fortiori the Code, at least as to inventory and accounts receivable transactions, fits into the same general framework.

101 The professor, who now spells his name MacLachlan, has elsewhere discussed the 1950 amendment. MacLachlan, Preference Redefined, 63 Harv. L. Rev. 1390 (1950).

102 See Ferguson v. Wilson, 122 Mich. 97, 80 N.W. 1006 (1899); Gay v. Bidwell, 7 Mich. 519 (1859).

103 In McLaughlin, Amendment of the Bankruptcy Act, 40 HARV. L. Rev. 341, 379, 385-90 (1927), Professor McLaughlin had taken a position disfavoring afteracquired property financing as to all but corporate debtors. 


\section{Language of Section 60}

Turning to the language of section 60 , again there is every reason to believe that Code transfers of future property will be non-preferential.

Section $60 \mathrm{a}(6)$ deals with equitable liens and declares them to be contrary to the policy of the Bankruptcy Act. ${ }^{104}$ But while the Massachusetts-rule after-acquired property lien runs directly afoul of this provision, neither the factor's lien nor the Code's security interest comes within its purview. It is certain from both the language of the Code and the nature of the secured status which it affords that its security interest in after-acquired property is "not merely an 'equitable' interest" ${ }^{105}$; it is a recorded, immediate interest subject to no subsequent gap in perfection. A Code security interest could be preferential, if at all, only under sections $60 \mathrm{a}(1)$ and (2)..$^{106}$

In determining when a transfer of personalty has been effected, section $60 \mathrm{a}(2)$ provides that it shall be considered to have been made "at the time when it became so far perfected that no subsequent lien upon such property obtainable by legal or equitable proceedings on a simple contract could become superior to the rights of the transferee." Since the interest of the Code dates for priority purposes from the filing of notice, there is no lien arising later than that time that can prevail against the property-except, of course, a purchase money secured interest. $^{107}$ As against lien creditors the security interest provided by

104 Section $60 \mathrm{a}(6)$ is quoted in relevant part in text below note 55 supra.

105 See UCC \$9-204, comment 2; Gilmore, The Secured Transactions Article of the Commercial Code, 16 LAw \& ConTEMP. ProB. 27, 35 (1951).

106 Some support for this thesis is found in 3 Collter $\$ 60.50$. Discussing the ordinary chattel mortgage on present property, Collier states: "If state law provides that a transfer gives rise to a 'legal' lien, as in the case of the ordinary chattel mortgage, it does not come within $\S 60 \mathrm{a}(6)$ but is governed by $\S 60 \mathrm{a}(2)$, and is to be judged as of the time it was perfected against subsequent lien creditors." Id. at 978 . "And will a recorded mortgage covering future property be considered 'perfected' as to the future property? ... Thus, in situations where there is a properly recorded mortgage purporting also to cover after-acquired property, the validity of the incumbrance on such property depends largely on the equitable lien doctrine. Consequently, if recordation does not give constructive notice as to the after-acquired property, good against both lien creditors and bona fide purchasers other than buyers in the ordinary course of trade,' subsequent perfection of the attempted lien should be regarded as preferential if the requisite elements are then present." Id. at 981. (Emphasis added.) The Code, which avoids all talk of equitable liens, also meets the Collier requirements of notice. Interestingly, it has been contended that even where the lien on afteracquired property is deemed to be equitable (in a chattel mortgage situation), $\S 60 \mathrm{a}(6)$ might still fail to make the lien preferential. See Comment, $50 \mathrm{Nw}$. U.L. REv. 541 (1955).

107 But such a claim cannot be deemed a "subsequent lien upon the property . . on a simple contract," Bankruptcy Act $\$ 60 \mathrm{a}(2)$; rather it is something in the nature of a prior claim arising against the property before the debtor acquires it. A purchase money interest holder has to be made an exception among the persons against whom filing will protect, in order to assure the debtor of 'a further outlet for secured financing. It would not seem that the "lien creditor" test of $\$ 60 \mathrm{a}(2)$ could reasonably be taken to include the purchase money creditor of after-acquired property. 
the Code is continuously perfected. The very acquisition of future property by the debtor operates automatically to extend the secured party's superior interest to that property, not through some later supplemental action necessarily invoking the doctrine of relation back, but by force of the after-acquired property clause of the security agreement itself. That agreement constitutes a single unitary transaction contemplating future acquisitions but whose future acquisitions, as part and parcel of the original agreement, are immediately perfected seriatim; they are not to be considered subsequent transfers for a then antecedent debt since they are controlled by operation of law upon acts of the parties consummated as of the date of execution and filing of notice of the agreement. ${ }^{108}$

\section{(2) Section 9-108 Is Possibly Self-Defeating}

The presence of section 9-108 indicates a concern by the draftsmen that in the absence of some special gimmick after-acquired property transfers would undergo serious danger of being regarded as preferential. This concern apparently stems from the impression-created perhaps by the predominance of Massachusetts-rule jurisdictions-that all after-acquired property clauses create unperfected equitable liens voidable in bankruptcy; the drafters failed to recognize the ample precedent for immunity afforded by cases dealing with automatic perfection transfers, especially under the Factors Lien Acts. But the very existence of section 9-108 might therefore lead a court to conclude that something in addition to original perfection is required, for if the draftsmen have not determined that the Code transactions are of such a nature as will fall without section 60 , how can the court? At the least

108 See UCC $\$ 9-204$, comment 2. Claussen and Hayes, in chattel mortgage transactions, and Roche, in a factors lien transaction, lend ample support to this proposition. A recent case that illustrates well, in a somewhat different context, the concept of a unitary transaction is Wolf v. Aero Factors Corp., 126 F. Supp. 872 (S.D.N.Y. 1954), aff'd, 221 F.2d 291 (2d Cir. 1955). Pursuant to a type of factoring arrangement (which is not detailed in the opinion) the bankrupt had assigned accounts receivable to the secured creditor. Under the particular revolving credit arrangement provided, some groups of accounts assigned within four months of bankruptcy turned out to be uncollectible and others were of greater value than the loan extended for them. The trustee claimed that only the credit extended at any one time was secured by the particular accounts assigned at that time and by no others, so that a part of the loan was unsecured even though the total amount of credit was less than the outstanding and collectible collateral. The court, however, reasoning that the accounts were assigned and credit extended pursuant to the terms of a master factoring agreement which specifically allowed any excess collateral from any particular transaction to offset any deficiency in collateral for any other transaction, held that since the debits and credits were all part of a single agreement, the assignee could set off the credit extended on worthless accounts against the excess of the other collateral under $\$ 68$ of the Bankruptcy Act. Some of the transfers of future accounts would seem to have been in satisfaction of past indebtedness and thus preferential if the court had not viewed the transactions as constituting a single unitary agreement. 
section 9-108 directs judicial attention to a problem which, it is submitted, does not exist.

Furthermore, in giving "new value" or contemporaneous value status to security interests attaching upon future property acquisition, the Code is clearly utilizing a fiction. ${ }^{109}$ There is thus strong likelihood that a court might treat such concepts as a sham and, looking skeptically at the time sequence of actual events, disregard the language. This result would seem even more likely when one regards the "new value" concept in the historical context of section 60: "new value" is in reality a relation forward of the consideration given for the security instrument to coincide with the acquisition of the future property - a mere reversal of the concept of relation back which was a specific target of the 1938 and 1950 amendments. And all this is not idle worry. Many of the commentators predict that section 9-108 will be treated as sham and that a preference hazard will remain to face Code financers. ${ }^{110}$

\section{(3) The Result Sought by Section 9-108 Is Commercially Desirable}

In present day commercial practice some of the most inherently valuable collateral is property to be acquired in the future ${ }^{111}$ and it would seem desirable to allow a secured creditor to finance against that property with safety. The Code itself attempts to free such financing from the challenges of all creditors except those with prior claims and perfected purchase money interests. But if a state adopts this principle through the instrumentality of the floating lien, ought the federal bankruptcy law to overturn such bona fide commercial transactions? What

109 The position taken by the National Commercial Finance Conference and the Association of Commercial Discount Companies, as represented by their opinions expressed in hearings before the NEW YoRK LAW REVISION CoMMITTEE, STUDY of UNIFORM COMMERCIAL CODE, ARTICLE NINE 1033 (1954), is that $\S 9-108$ creates a fiction. Accord, Comment, 67 Yale L.J. 402, 417 n.44 (1958). But Everett, Securing Security, 16 LAw \& CONTEMP. PROB. 49, 55 (1951), states that this section has not "called black white, called old value new," because in any event such financing is typically done through revolving credit arrangements. See note 112 infra. This observation, of course, fails to speak directly to the problem, which is concerned precisely with the instance where the revolving credit plan is not in fact used.

110 The following articles express doubt as to the effectiveness of §9-108: Kripke, The Modernization of Commercial Security Under the Uniform Commercial Code, 16 LAW \& Contemp. ProB. 183 (1951); Kripke, The "Secured Transactions" Provisions of the Uniform Commercial Code, 35 VA. L. REv. 577 (1949); Kupfer, Accounts Receivable, Trust Receipt, and Related Types of Financing Under Article Nine of the Uniform Commercial Code, 27 Tearp. L.Q. 278 (1953); Comment, 2 Villa. L. Rev. 395 (1957) ; Comment, 67 YALE L.J. 402 (1958). All operate on the assumption that in the absence of this section there exists a preference problem. Everett, supra note 109, and Birnbaum, Article 9-A Restatement and Revision of Chattel Security, 1952 Wrs. L. REv. 348, are more optimistic about the fate of $\$ 9-108$, but they, too, proceed on the theory that there is a problem to be met.

111 In inventory and accounts receivable financing this is especially true. See Lowenstein, Assignments of Accounts Receivable and the Bankruptcy Act, 1 RuTGERS L. REv. 1 (1947); Note, 101 U. PA. L. REv. 392 (1952). 
a windfall to the general creditor who had long been on constructive notice that the debtor's future assets were to be made a part of the secured creditor's collateral! Custom and usage of financing under the Code will provide such creditors with the experience necessary for determining whether or not to extend credit to a debtor who has executed a security instrument covering after-acquired property. They need only check the records to protect themselves. The preference section amendments aimed at voiding secret and unperfected transactions. Certainly the Code's security interest scheme is not vulnerable to these objections.

If the bankruptcy courts strike down Code after-acquired property interests as preferences, secured creditors may have to finance against future property by use of the revolving credit plan. ${ }^{112}$ Such a plan will accomplish for the secured creditor the same result, but the financing will be a much more expensive undertaking. Furthermore, the plan necessitates policing, which the Code has dispensed with. ${ }^{113}$

If sound commercial practice is looked to to support the proposition that Code transfers ought not to be voided as preferences, then section 9-108 does contain a meritorious limitation upon the class of property whose encumbrance may be regarded as nonpreferential. The section provides that only future property acquired "in the ordinary course of business or under a contract of purchase made pursuant to the security agreement within a reasonable time after new value is given" is to be considered transferred for a new, not antecedent debt; this substantially limits section 9-204 which would permit a financer to encumber virtually all the debtor's property. By restricting protection to commercial transactions, the draftsmen have recognized that a secured creditor is entitled to rely on the general business assets of his debtor but not, as against the trustee in bankruptcy, on unusual, uncontemplated acquisitions. Since his secured financing envisioned only expected business turnoveradditions to and replacement of assets-his secured claim is to be treated as a transfer for an antecedent debt as to unanticipated, remote or nonbusiness acquisitions by the debtor. This is more in accord with the nature of the secured creditor's reliance. It is more in accord, also, with the bankruptcy theme of equality of distribution, ${ }^{114}$ since, were the law otherwise, the secured creditor alone would receive windfall benefits.

112 Under a revolving credit plan the practice is for the debtor to pay the proceeds of the sales or accounts to the secured creditor who makes an immediate remittance of the proceeds back to the debtor in a formal exchange for the afteracquired collateral. For a discussion of how this practice has obviated state law restrictions on floating liens see Gilmore, supra note 105 . See also Everett, supra note 109; Note, 101 U. PA. L. REv. 392 (1952).

113 Secured creditors police the transactions in any case when there is danger of dishonesty or insolvency. See Note, 101 U. PA. L. REv, 392 (1952).

1143 COLLIER $\$ 60.01$. 
The test provided, moreover, is flexible and can easily be adapted to the operational needs of any business.

It is in this limitation indeed that section 9-108 has its true merit. However, since a court might well regard the section as ineffective to resist a preference challenge, its amendment should be recommended.

\section{(4) Recommended Amendment of 9-108}

In approaching the problem of amendment, we may borrow profitably from the concepts developed in such cases as Mitchell and Roche. It will be remembered that in Mitchell Mr. Justice Story, upholding the present transfer of future property, analogized from the equity-sanctioned assignment of expectancies and future claims. In a fairly recent case involving such an assignment, ${ }^{115}$ a bankrupt had assigned, by a transaction in the nature of a sale, the expectancy she might receive by will or by intestacy from her father's estate. The assignment was made some four years before her bankruptcy. Her father died the day following bankruptcy, her expectancy then matured into a definitely determinable asset, and the trustee sued to set aside the transfer as a preference. The Second Circuit, under the 1938 amendment to section 60, said that New York law enabled an expectancy to be presently transferred even though it could mature, if at all, only at some uncertain date in the future. Under New York law a lien created by an after-acquired property clause in a mortgage would have been deemed unperfected as against lien creditors until possession was taken; the assignment of the expectancy, on the other hand, was regarded as fully and completely transferred at the date of assignment, and-if in a security instrumentperfected as of that date. Thus the court would not consider the assignment as in the nature of a transfer of after-acquired property. Rather it was deemed to be a present transfer of something like a "present right." In effect the court treated the assignment as if it were a transfer of a present property right in a future contingency, because state law had determined that such an expectancy was an existent res. ${ }^{116}$ And in a somewhat analogous case, ${ }^{117}$ where there had been an assignment of future payments that would be due under an existing but unperformed bilateral contract, the court held that the payments which were made

115 In re Barnett, 124 F.2d 1005 (2d Cir. 1942).

$110^{\prime \prime}$ The New York cases . . showed that certain types of equitable liens, especially those created by mortgages and pledges of after-acquired property, could not withstand the onslaught of creditors who obtained judgment before the mortgagee or pledgee took possession. . . . It is not our duty, of course, to explain why the $\mathrm{New}$ York courts distinguish between the validity of mortgages and pledges of after-acquired property, and assignments of expectancies." Id. at 1008.

117 Rockmore v. Lehman, 129 F.2d 892 (2d Cir. 1942). 
pursuant to the assignment within four months of bankruptcy were not preferential. The court reasoned that there could be a present assignment of the moneys to be earned because there was an underlying present res, the contract, out of which the payments were to arise. This was a present transfer even though the contract itself was not assigned and the contract was still executory.

In both cases the court concerned itself primarily with the question of whether or not state law recognized the transferability of these intangibles. Once having decided that state law did permit their transfer, it concluded that there was a present "property" or "right" or "interest" that existed and was assigned. Under such an analysis, the court was not concerned with the future property aspects of the transfers. ${ }^{118} \mathrm{New}$ York had determined for itself what should and what should not be "future property." An expectancy is not future property but is a present right of sorts. An assignment of future payments on an unperformed contract is not a transfer of future property, but is a transfer of an existing contract right. ${ }^{119}$ New York might have said that these

$118 \mathrm{New}$ York law in this area is exceedingly complex and indeed almost irrational. An assignment of a fund to be created if the debtor's license application is denied and his money refunded is presently assignable and perfected. Capitol Dist. Corp. v. 2131 Eighth Ave., Inc., 1 N.Y.2d 842, 135 N.E.2d 726 (1956). But the assignment of a fund to be created by the refund of money upon cancellation of an issued liquor license is not presently perfected. New York v. Bedford Bar \& Grill, Inc., 2 N.Y.2d 429, 141 N.E.2d 575 (1957). See also In re Modell, 71 F.2d 148 (2d Cir. 1934) (assignment of judgment of pending tort litigation one and onehalf years before verdict found to be preferential even under the pre-1938 $\$ 60$ because New York did not recognize the present perfection of such an assignment and had no relation back doctrine to save the equitable lien on after-acquired property); Williams v. Ingersoll, 89 N.Y. 508 (1882) (assignment of future proceeds of pending tort litigation held superior to subsequent attachment made after entry of arbitrator's award but before date fixed for payment of award). When the transfer is found "presently perfected" the courts seem to imply that there is a present property right assigned ; otherwise there is a "mere equitable lien" on future property-future property that is found to be assignable but not perfected. In the Rockmore and Barnett situations the court finds the future property linked to a present res of some sort that makes the assignment perfected in presenti as well as transferred in presenti: the court seems to discover something in the present that gives the future property "potential existence" Once determined that the present res is good enough to support the future contingency, it finds present perfection of the assignment. The dissent in the Bedford case, supra, is interesting: "While this is the rule [that lien creditors can prevail] with regard to the mortgage or pledge of future crops or afteracquired chattels, it is not the general rule, and neither the rule (as to such crops and chattels) nor the reasons therefor have ever been applied by us to the assignment of a fund which is to come into existence out of a present property right, and which fund was advanced by the assignee. We have held, in a wide variety of circumstances, that where the fund is to arise out of an existing relationship between the assignor and the potential source of the fund, such an assignment is valid as against creditors of the assignor who acquire liens after the fund comes into existence." 2 N.Y.2d at 435,141 N.E.2d at 578. (Emphasis added; court's emphasis omitted.) See in this connection note 119 infra.

110 Concerning the concept of future property presently perfectible as well as presently assignable, with special regard to contract rights and accounts receivable, see Lowenstein, supra note 111, at 8: "It is submitted, however, that the rule, granting present binding effect to an assignment of future book accounts to arise under prospective contracts, has much in its favor and is consistent with the cases upholding 
transactions involved-like after-acquired property clauses in chattel mortgages-transfers of future property. But New York had not. And the bankruptcy court chose to treat the transfers as present property. But if state law could make this determination and if the bankruptcy court accepted state law distinctions, it would not seem illogical to treat inventory, accounts receivable, and other commercial future property transfers similarly. This is exactly what the Roche case did for inventory under the New Hampshire Factors Lien Law. It regarded the inventory as a continuing res and the future acquisitions as potentially present because business operation necessitates inventory turnover. The Factors Lien Act did not specifically construct the res found by the court, but the act was read to provide it.

It is within this type of analytic framework that a recommendation for amending the Code should be made. It is not clear whether the Code in its present form will be construed to contain the concept of the existing res. The similarity between the Code and the Factors Lien Act has already been mentioned, but it must be remembered that the Comet case did not interpret the New York Factors Lien Act in terms of an existing res, and such a construction of the Code would seem especially doubtful in view of the existing form of section 9-108, whose relation-forward approach would be totally unnecessary under the Roche analysis. It is therefore recommended that section $9-108$ be amended to read:

"Where a secured party makes an advance, incurs an obligation, releases a perfected security interest, or otherwise gives new value which is to be secured in whole or in part by after-acquired property his security interest in the after-acquired collateral shall be deemed a present transfer of a present expectancy interest in the future property, if the debtor acquires his rights in such collateral either in the ordinary course of his business or under a contract of purchase made pursuant to the security agreement within a reasonable time after new value is given.

\section{Comment:}

"The transfer of the future property is to be regarded as a present transfer of an existing property right of 'potential' existence. It is a present contingent property res. The existence of the debtor's business furnishes the present property out of which the future contingency can arise."

present assignments of other expectancy interests." See also Comment, 67 YALE L.J. 847, 860 (1958): "But in many business contexts, future rights are no less susceptible to description or less definite in value than future performances arising under existing contracts." Both articles advocate the free amenability of future properties to presently perfectible assignments because of the potential existence grounded in their existing relation to an established business practice. 